\title{
Thiosulphate Metabolism and Rhodanese in Chromatium sp. strain D
}

\author{
BY A. J. SMITH* AND JUNE LASCELLES \\ Microbiology Unit, Department of Biochemistry, University of Oxford
}

(Received 27 August 1965)

\begin{abstract}
SUMMARY
Suspensions of Chromatium D oxidized thiosulphate completely to sulphate (in the light) under anaerobic conditions in the presence of carbon dioxide. During the oxidation, intracellular sulphur accumulated transiently and sulphate production followed a biphasic pattern. Using inner- ${ }^{35}$ S-thiosulphate, the initial burst of sulphate production, which accounted for about half of the total yield, occurred principally at the expense of the inner $\left(\mathrm{SO}_{3}^{-}\right)$atom of thiosulphate; there was no intracellular accumulation of labelled sulphur. The radioactivity from outer- ${ }^{35} \mathrm{~S}$-thiosulphate accumulated transiently within the organisms and was transferred to sulphate at a rate which was similar to the second phase of sulphate production; most of the outer (S-) atom therefore passed through the stage of endogenous sulphur. Extracts of the organism catalysed the cyanolysis of thiosulphate to give sulphite and thiocyanate. An assay for this enzyme, rhodanese, based on the spontaneous reduction of 2,6-dichlorophenol-indophenol by sulphite was developed. The enzyme was also detected in extracts of Athiorhodaceae. The enzyme was partially purified from extracts of Chromatium $D$ and resolved into two active fractions. It is concluded that endogenous sulphur is an intermediate in the oxidation of thiosulphate by Chromatium $D$ and that the cleavage of the $S-S$ bond in the molecule is a key step in the oxidation process. Rhodanese, which catalyses this type of reaction, may be concerned in this cleavage.
\end{abstract}

\section{INTRODUCTION}

Photosynthetic sulphur bacteria assimilate carbon dioxide into cell material under anaerobic conditions in the light with the concomitant oxidation of a variety of reduced inorganic sulphur compounds to sulphate or to an intermediate oxidation product such as sulphur (van Niel, 1931; Larsen, 1952, 1953). The ability of purple sulphur bacteria (Thiorhodaceae) to accumulate globules of sulphur intracellularly during autotrophic growth on sulphide and thiosulphate is a characteristic feature of these organisms (van Niel, 1931, 1936; Eymers \& Wassink, 1937). The role of endogenous sulphur in the oxidation of thiosulphate by Thiorhodaceae is uncertain.

The oxidation of inorganic sulphur compounds has been studied more intensively with thiobacilli which oxidize them under aerobic conditions in the dark to sulphate or intermediate oxidation products such as polythionates and elementary sulphur. The accumulation of extracellular sulphur during such processes has been variously attributed to biological reactions (Starkey, 1935; Peck, 1960) and to spontaneous

* Present address: Bacteriology Department, University of California, Berkeley, California, U.S.A. 
reactions (Tamiya, Haga \& Huzisige, 1941; Vishniac, 1952; Rittenberg \& London, 1964). The results of experiments both with whole organisms and with extracts has led to two differing schools of thought concerning the mechanism of the initial attack on thiosulphate:

(1) the oxidative coupling of two molecules to give tetrathionate (Trudinger, 1958, 1959; Vishniac \& Santer, 1957; Rittenberg \& London, 1964);

(2) the reductive cleavage of one molecule to give sulphide and sulphite (Peck, 1960 ; Peck \& Fisher, 1962).

In the present work, the metabolism of thiosulphate and other inorganic sulphur compounds has been studied in the purple sulphur bacterium Chromatium strain $D$ to establish the mechanism of thiosulphate oxidation and the role of intracellular sulphur in this process. In the course of this work thiosulphate sulphur-transferase activity was demonstrated in extracts. This enzyme catalyses the cyanide-dependent cleavage of thiosulphate to form thiocyanate and sulphite (equation 1) and has been extensively studied with purified preparations from mammalian sources such as liver and kidney (Green \& Westley, 1961; Westley \& Nakamoto, 1962). In the presence of reduced lipoic acid $\left(\mathrm{Lip}(\mathrm{SH})_{2}\right)$ the enzyme catalyses the reductive cleavage of thiosulphate (equation 2); lipoyl persulphide is an intermediate in this reaction (Villarejo \& Westley, $1963 a, 1963 b$ ).

$$
\mathrm{S}_{2} \mathrm{O}_{3}{ }^{2-}+\mathrm{Lip}(\mathrm{SH})_{2} \rightarrow \mathrm{SO}_{3}{ }^{2-}+\mathrm{Lip}^{2-} \mathrm{CNH}_{\mathrm{SH}}^{\mathrm{SSH}} \rightarrow \mathrm{Lip}(\mathrm{S})_{2}+\mathrm{SO}^{2-} \text {. }
$$

Thiosulphate sulphur-transferase EC 2.8.1.1. (which will be referred to as rhodanese) has been partially purified from Chromatium $D$ and its possible relevance to thiosulphate metabolism has been examined. This work has been briefly reported elsewhere (Smith, 1964, 1965).

\section{METHODS}

Organisms. The culture of Chromatium sp. strain D and its maintenance as stab cultures on the thiosulphate + salts medium have been previously described (Hurlbert \& Lascelles, 1963). This organism was used throughout these studies except in the investigations with extracts where the Athiorhodaceae, Rhodospirillum rubrum and Rhodopseudomonas spheroides were also used. These organisms were grown anaerobically in the light on the malate + glutamate medium described by Lascelles (1959) fortified in the case of Rhodospirillum rubrum with yeast extract $(0 \cdot 2 \%, \mathrm{w} / \mathrm{v})$.

Media. The thiosulphate + bicarbonate + salts medium used for the growth of Chromatium D was that described by Hurlbert \& Lascelles (1963). In some experiments organic substrates were used in place of thiosulphate, as described previously.

Growth of cultures. In preparing organisms for experiments with suspensions and cell-free extracts the inoculum was taken from a stab culture or from a liquid culture for volumes in excess of $1 \mathrm{l}$. (approximately $1 \mathrm{ml}$. of liquid culture/100 ml. of medium). The cultures were incubated in completely filled glass-stoppered bottles at $34^{\circ}$ in a light cabinet fitted with banks of $15 \mathrm{~W}$. tungsten lamps. The organisms were free of endogenous sulphur and fully grown after 2-4 days. 
For the quantitative investigation of growth on various inorganic sulphur compounds, sulphide $(0.01 \%, w / v)$ and thiosulphate (up to $0.3 \%, w / v)$ were omitted from the complete salts medium and replaced by the appropriate sulphur compound The inoculum, taken from a liquid culture, gave an initial concentration equiv. $30 \mathrm{mg}$. protein/l.; for growth on endogenous sulphur, the initial concentration equiv. was $70 \mathrm{mg}$. protein/l. The inoculated medium was incubated in Roux bottles under oxygen-free nitrogen in a glass-sided water bath at $34^{\circ}$ illuminated with $150 \mathrm{~W}$. tungsten lamps $15 \mathrm{~cm}$. from the bath; the light intensity was approximately $150 \mathrm{ft} . c$. at the surface of the vessel. The densities of the cultures were measured at the end of growth as protein determined by the biuret method described by Hurlbert \& Lascelles (1963). The protein: dry weight ratios of organisms grown on various inorganic sulphur compounds were in the range $0 \cdot 5-0 \cdot 6$.

Preparation and incubation of suspensions. Organisms were normally harvested from the thiosulphate + salts medium at the end of growth when largely free of endogenous sulphur by centrifuging at $2500 \mathrm{~g}$ for $15 \mathrm{~min}$., washed twice in about one-fifth the original culture volume of $0.04 \mathrm{M}$-potassium phosphate buffer $(\mathrm{pH} \mathrm{7.5})$ and resuspended in $0.1 \mathrm{M}$-potassium phosphate buffer ( $\mathrm{pH} \mathrm{6.75)}$ containing sodium bicarbonate $(60 \mathrm{~mm})$ and sodium thiosulphate $(2-40 \mathrm{~mm})$. Suspensions were incubated at $34^{\circ}$ and gassed continuously with $\mathrm{N}_{2}+5 \% \mathrm{CO}_{2}$; the final $\mathrm{pH}$ was $7 \cdot 3$. For investigations at low intensities of illumination, suspensions containing up to $2.0 \mathrm{mg}$. protein $/ \mathrm{ml}$. were incubated in flat-sided glass bottles in a glass-sided water bath as described above. Incubations at higher intensities of illumination (up to $500 \mathrm{ft} . c$. at the level of the suspension) were made in a photosynthetic Warburg tank (American Instrument Co., Inc., Washington, D.C.) illuminated from below with a bank of twelve $100 \mathrm{~W}$. tungsten lamps coupled to a rheostat. Suspensions containing $0 \cdot 2-0.5 \mathrm{mg}$. of protein $/ \mathrm{ml}$. were incubated in this bath in flatbottomed conical flasks shaken transversely at $100 \mathrm{cyc} . / \mathrm{min}$. with an amplitude of $4 \mathrm{~cm}$.

Preparation of extracts. Organisms were normally harvested at the end of growth when largely free of endogenous sulphur by centrifuging at $2500 \mathrm{~g}$ for $15 \mathrm{~min}$., washed twice in one-tenth the original culture volume of $0.04 \mathrm{M}$-potassium phosphate buffer ( $\mathrm{pH} \mathrm{6 \cdot 1)}$ and resuspended in the same buffer at concentrations to $50 \mathrm{mg}$. protein $/ \mathrm{ml}$. Crude extracts were prepared by the French press or by ultrasonic treatment (Hurlbert \& Lascelles, 1963). They were centrifuged at $18,000 \mathrm{~g}$ for $20 \mathrm{~min}$. to remove whole organisms and debris. Cell breakage and all subsequent fractionations were done at $0-5^{\circ}$; extracts and extract fractions were stored at $-20^{\circ}$.

Assay for rhodanese. The reaction mixture contained, in a volume of $3 \mathrm{ml}$.: tris buffer (pH 8.7), $300 \mu$ mole; sodium thiosulphate, $150 \mu$ moles; half neutralized sodium cyanide ( $\mathrm{NaCN} / \mathrm{HCl}, 2 \cdot 5 / 1$., mole/mole), 150-240 $\mu$ moles; 2,6-dichlorophenol-indophenol (DCIP), $0.5 \mu$ mole; $N$-methylphenazoniummethosulphate (PMS), 0.25 mg.; enzyme preparation equivalent to $0.5 \mathrm{mg}$. of crude extract protein. The reaction was initiated by the addition of cyanide to the otherwise complete reaction mixture. The reference cuvette contained the complete reaction mixture without thiosulphate. DCIP reduction was followed at room temperature $\left(18-20^{\circ}\right)$ using a recording double-beam grating spectrophotometer (Optica type CF 4DR Optica U.K. Ltd., Gateshead-on-Tyne, England). The millimolar extinction coeffi- 
cient of DCIP at $600 \mathrm{~m} \mu$ is $19 \cdot 1$ (Basford \& Huennekens, 1955). The unit of enzyme activity was defined as the amount of enzyme which catalysed the reduction of $30 \mathrm{~m} \mu$ mole of DCIP/min.

Purification of rhodanese. Particle-bound pigment was removed from the extract prepared from $12 \mathrm{l}$. of fully grown culture by centrifuging at $100,000 \mathrm{~g}$ for $60 \mathrm{~min}$. in a Spinco model $\mathrm{L}$ ultracentrifuge. The supernatant fraction was treated with $\mathbf{5} \%$ (w/v) streptomycin sulphate (Glaxo Laboratories Ltd., Greenford, England) in 0.04 M-potassium phosphate buffer $(\mathrm{pH} 6 \cdot 1)$ to a final concentration of $0.6 \mathrm{mg}$. of streptomycin sulphate/mg. extract protein. Precipitated nucleic acid was removed after $15 \mathrm{~min}$. by centrifuging at $18,000 \mathrm{~g}$ for $20 \mathrm{~min}$. Protein was precipitated from the supernatant fluid with saturated ammonium sulphate $(\mathrm{pH} \mathbf{7 \cdot 0}$ ) at a final concentration of $90 \%$ saturation (by volume). After $30 \mathrm{~min}$., the precipitated protein was removed by centrifuging at $18,000 \mathrm{~g}$ for $20 \mathrm{~min}$., and was redissolved

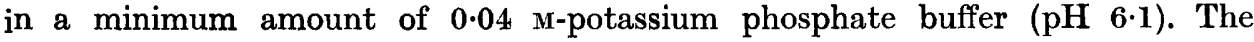
concentrated protein fraction was applied to a column $(35 \times 1.5 \mathrm{~cm}$. $)$ of Sephadex $\mathrm{G} 75$

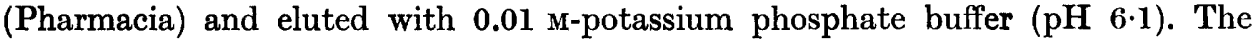
enzyme recovered from the column was transferred to a column $(10 \times 1.5 \mathrm{~cm}$.) of DEAE-DE 50 cellulose (Whatmans.). Protein was eluted with potassium phosphate buffer ( $\mathrm{pH} \mathrm{6.1)} \mathrm{using} \mathrm{a} \mathrm{concentration} \mathrm{gradient} \mathrm{(10-500} \mathrm{mm}$ ); the flow rate was $2 \mathrm{ml} . / \mathrm{min}$. and the eluate was collected in $5 \mathrm{ml}$. fractions.

Analytical methods. With crude extracts, protein was precipitated and pigments were removed by heating the samples to $65^{\circ}$ with $5 \mathrm{ml}$. of acid ethanol $(400 \mathrm{ml}$. of ethanol, $5 \mathrm{ml}$. of glacial acetic acid and $100 \mathrm{ml}$. of water). The extraction procedure was repeated at least twice. The protein suspension was collected by centrifuging and the protein determination carried out as described by Hurlbert \& Lascelles (1963). Protein determinations at all stages of extract fractionation after the removal of pigments from the crude extract were made by u.v. absorption (Layne, 1957).

The concentrations of thiosulphate and sulphate in suspensions were determined using samples of the supernatant fluid after the organisms had been removed by centrifuging. Thiosulphate was determined titrimetrically with standardized iodine, and by the methods of Schöön (1959) and Sorbo (1957). Sulphate was determined by the method of Gleen \& Quastel (1953).

An approximate estimate of the accumulation of sulphur within the organisms in a suspension oxidizing thiosulphate was made by following the change in turbidity of the suspension with an EEL photoelectric colorimeter with a neutral density filter (Evans Electroselenium Ltd., Halstead, Essex, England.).

Phosphate was determined by the method of Taussky \& Shorr (1953).

Measurement of ${ }^{35} \mathrm{~S}$ in the organisms and sulphate in suspensions. For determination of radioactivity in the organisms, samples of suspension containing $0.06 \mathrm{mg}$. protein were drawn through cellulose plastic filters under vacuum (Millipore filters of pore size 0.65 $\mu$ held in a Pyrex microanalysis filter-holder; Millipore Filter Corporation, Bedford, Mass., U.S.A.). The organisms on the filter were washed with water. Samples for the determination of ${ }^{35} \mathrm{~S}$ in the sulphate were centrifuged to remove the organisms. Supernatant fluid containing up to $6 \mu$ mole sulphate was made up to $9 \mathrm{ml}$. with water and mixed with $1 \mathrm{ml}$. of reagent $(15 \mathrm{~g}$. of barium chloride and $4.8 \mathrm{ml}$. of concentrated hydrochloric acid in $100 \mathrm{ml}$. of water); samples of the sus- 
pension containing up to $0.7 \mathrm{mg}$. dry weight of barium sulphate were drawn through cellulose plastic filters under vacuum and washed with water.

The filter pads containing organisms and barium sulphate were dried at room temperature and glued to aluminium foil planchets. Samples were counted with an end-window Geiger-Müller tube (EHM25, General Electric Co., England) in a lead castle coupled to an Ecko Automatic Scaler (type N530D, Ecko Electronics Ltd., England). Self-absorption was negligible and the counts were corrected for background. The efficiency of counting was approximately $3.5 \%$.

Chemicals. Tetrathionate was prepared by the method of Gilman (1946).

The sodium salts of inorganic sulphur compounds were used throughout these studies.

${ }^{35}$ S-thiosulphates were obtained from the Radiochemical Centre (Amersham, Bucks., England). The original specific activities were in the range 10-20 mc./ $\mu$ mole.

\section{RESULTS}

\section{Growth of Chromatium D}

Autotrophic growth of the organism was supported by sulphide, sulphur, thiosulphate and sulphite ('Table 1); intracellular sulphur accumulated transiently during growth on sulphide and thiosulphate and such endogenous stores of sulphur supported the further growth of the organism on the salts medium in the absence

\section{Table 1. Growth of Chromatium D on inorganic sulphur compounds}

The basal salts medium, containing $0.5 \% \mathrm{NaHCO}_{3}$, was supplemented with thiosulphate, sulphide, sulphite or tetrathionate, each at a final concentration of $4 \mathrm{~mm}$. Organisms that were in the stationary phase and largely free of sulphur were used as the inoculum. In the experiment showing growth on endogenous sulphur, organisms were harvested during growth on thiosulphate when packed with sulphur and used as the inoculum for sterile sulphur-free salts medium (see Methods section). Another sample of these organisms was incubated in the suspension medium at a concentration of $1.5 \mathrm{mg}$. protein/ml. for several hours; the sulphate produced was determined and used as a measure of the intracellular sulphur. Growth was estimated as the increase in protein, when the cultures had reached the stationary phase.

Sulphur compound

Thiosulphate

Sulphide

Sulphite

Sulphur (endogenous)

Tetrathionate

Tetrathionate + thiosulphate
Growth yield (mg. protein/mmole)

27
27
6
19
No growth
No growth

Reducing capacity (electrons/molecule)

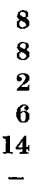

of added sulphur compounds (Table 1). Tetrathionate did not support the autotrophic growth of the organism and the polythionate inhibited the growth of the organism on thiosulphate (Table 1). It also inhibited growth on organic compounds such as pyruvate and succinate.

Under autotrophic conditions the extent of growth was dependent on the amount of sulphur compound in the medium and, on a molar basis, was proportional to the number of electrons released during oxidation of the sulphur compound to sulphate (Table 1). 


\section{Oxidation of inorganic sulphur compounds by suspensions of Chromatium D}

Thiosulphate oxidation. Suspensions of inorganic grown organisms in phosphate buffer and bicarbonate, at $\mathrm{pH} \mathbf{7 \cdot 3}$, oxidized thiosulphate completely to sulphate under anaerobic conditions in the light (Fig. 1). The production of sulphate from thiosulphate followed a biphasic pattern. The rapid disappearance of thiosulphate was accompanied by the rapid production of up to $60 \%$ of the theoretical yield of sulphate and the intracellular accumulation of sulphur. When thiosulphate had disappeared, sulphate was produced at a much slower rate, presumably from the endogenous sulphur which had accumulated during the initial period. Under these conditions, tetrathionate was not detected in suspensions during thiosulphate oxidation. The rates of thiosulphate disappearance and of sulphur accumulation were dependent on the intensity of illumination in the range 0-200 ft.c. Above the light saturation point, the rate of thiosulphate disappearance was strictly dependent on the density of the suspension. The kinetics of thiosulphate utilization and sulphate production by suspensions were, however, similar at both low (150 ft.c.) and high (500 ft.c.) intensities of illumination.

\section{Table 2. Thiosulphate oxidation by suspensions of organisms under various conditions}

\begin{tabular}{|c|c|c|}
\hline Conditions & $\begin{array}{l}\text { Thiosulphate } \\
\text { disappearance } \\
(\mu \text { mole } / \mathrm{hr} / \mathrm{ml} .)\end{array}$ & $\begin{array}{l}\text { Sulphate produced } \\
\text { after } 20 \mathrm{hr} \\
\text { (\% theoretical) }\end{array}$ \\
\hline $\begin{array}{l}\text { Anaerobic dark } \\
\text { Anaerobic light }\end{array}$ & $\begin{array}{l}0 \\
2 \cdot 9\end{array}$ & $\begin{array}{r}0 \\
96\end{array}$ \\
\hline $\begin{array}{l}\text { Aerobic, dark } \\
\text { Aerobic, light }\end{array}$ & $\begin{array}{l}2 \cdot 2 \\
5 \cdot 3\end{array}$ & $\begin{array}{l}62 \\
72\end{array}$ \\
\hline
\end{tabular}

The oxidation of thiosulphate was not affected by the omission of phosphate, by the addition of organic compounds (pyruvate, $10 \mathrm{~mm}$; succinate, $10 \mathrm{~mm}$ ), or by the presence of considerable amounts of endogenous sulphur within the organisms of the suspension. Under anaerobic conditions, thiosulphate did not disappear in the absence of the physiological oxidant, bicarbonate, or in the dark. Under aerobic conditions (gas phase, air/ $\mathrm{CO}_{2}$ ), however, thiosulphate oxidation by suspensions was not light-dependent but was increased by illumination (Table 2).

Oxidation of other inorganic sulphur compounds. Suspensions of thiosulphategrown organisms harvested during growth, when they contained considerable amounts of intracellular sulphur, oxidized this endogenous sulphur to sulphate under anaerobic conditions in the light. Sulphate production was accompanied by a fall in the turbidity of the suspension (Fig. 2). The fact that organisms oxidized endogenous sulphur to sulphate enabled an estimate to be made of the magnitude of sulphur accumulation during growth on thiosulphate. Determination of the sulphate produced by organisms harvested when they contained much intracellular 


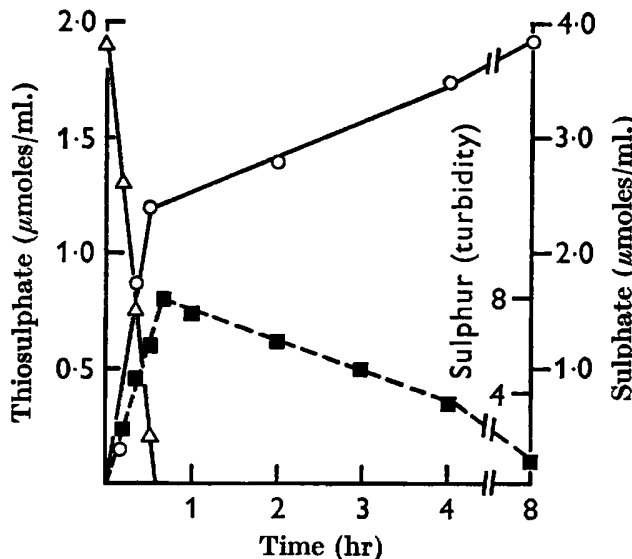

Fig. 1.

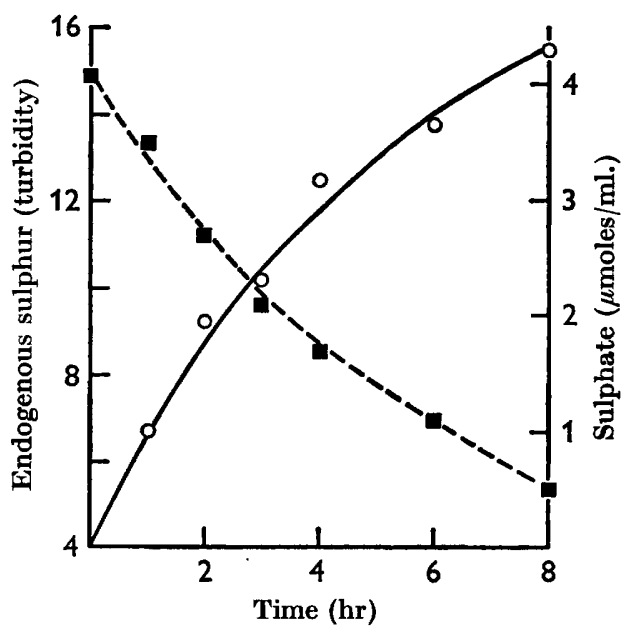

Fig. 2.

Fig. 1. Oxidation of thiosulphate by a suspension of Chromatium D. A suspension of thiosulphate-grown organisms containing $0.25 \mathrm{mg}$. of protein $/ \mathrm{ml}$. was incubated under anaerobic conditions at a light intensity of $500 \mathrm{ft}$.c. in the presence of thiosulphate (2 mM). Thiosulphate $(-\triangle-)$ disappearance, sulphur (-----) accumulation and sulphate $(-\mathrm{O}-$ ) production were determined, as described in the Methods section.

Fig. 2. Oxidation of endogenous sulphur. A suspension of thiosulphate-grown organisms $(0.25 \mathrm{mg}$. of protein $/ \mathrm{ml}$.) containing endogenous sulphur was incubated under anaerobic conditions at a light intensity of $500 \mathrm{ft.c}$. Sulphur (-- ---$)$ utilization and sulphate (-O-) production were determined.

\section{Table 3. Oxidation of inorganic sulphur compounds by suspensions of organisms}

Suspensions of thiosulphate-grown organisms (1.5 mg. of protein/ml.) were incubated under anaerobic conditions at a light intensity of $150 \mathrm{ft} . c$. with the appropriate sulphur compound-sulphide $(10 \mathrm{~mm})$, sulphite $(10 \mathrm{~mm})$, thiosulphate $(10 \mathrm{~mm})$ or exogenous elementary sulphur. In the experiment showing the oxidation of endogenous sulphur, the organisms contained much intracellular sulphur when harvested. The rate of sulphite oxidation was corrected for the spontaneous reaction and the figures quoted for thiosulphate refer to the first and second phases of sulphate production.

$\begin{array}{lc} & \begin{array}{c}\text { Rate of sulphate } \\ \text { production } \\ (\mu \mathrm{mole} / \mathrm{hr} / \mathrm{ml} .)\end{array} \\ \text { Sulphur compound } & 6 \cdot 2 \\ \text { Thiosulphate } & 1 \cdot 1 \\ & 1 \cdot 0 \\ \text { Sulphide } & 0 \cdot 4 \\ \text { Sulphur (exogenous) } & 1 \cdot 4 \\ \text { (endogenous) } & \mathbf{5 \cdot 4}\end{array}$

sulphur showed that endogenous sulphur accounted for up to $27 \%$ of the dry weight of the organisms.

Sulphide, exogenous sulphur and sulphite were oxidized to sulphate by the suspensions (Table 3). Sulphur accumulated intracellularly during the oxidation of sulphide but not of sulphite. The suspensions did not oxidize tetrathionate to sulphate under anaerobic conditions in the light. 


\section{Oxidation of ${ }^{35} \mathrm{~S}$-thiosulphates}

The kinetics of thiosulphate utilization and of sulphate production suggested that the accumulation of intracellular sulphur represented an intermediate stage in the oxidation of thiosulphate to sulphate by the suspensions. This possibility was examined with ${ }^{35} \mathrm{~S}$-thiosulphate labelled in the inner $\left(\mathrm{SO}_{3^{-}}\right)$and outer (S-) atoms. The magnitude of intracellular sulphur accumulation and the origin of this sulphur was also determined by such isotopic techniques. Radioactivity was measured in the sulphate produced and in the organisms of the suspensions (as described in the Methods section).

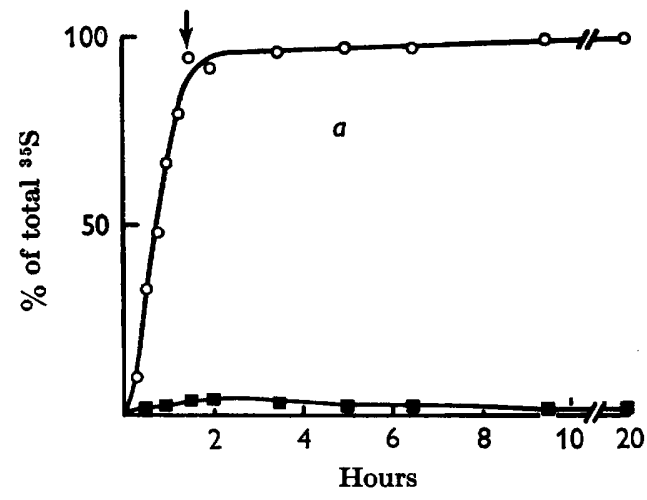

Fig. $3 a$.

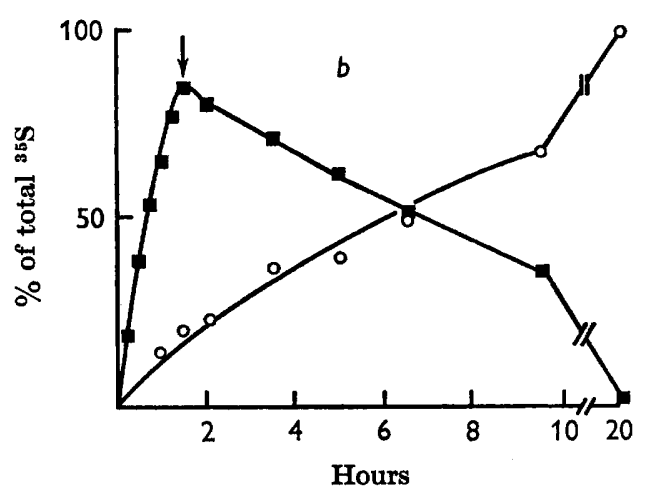

Fig. $3 b$.

Fig. 3. Labelling of organisms and sulphate in suspensions oxidizing ${ }^{35} \mathrm{~S}-$ thiosulphates. Similar suspensions of thiosulphate-grown organisms containing $0.25 \mathrm{mg}$. protein $/ \mathrm{ml}$. were incubated under anaerobic conditions at a light intensity of $500 \mathrm{ft} . c$. in the presence of $(a)$ inner $\left(\mathrm{SO}_{3^{-}}\right)$and $(b)$ outer (S-) labelled thiosulphate $(4 \mathrm{mM} ; 0.1 \mu \mathrm{c} . / \mu \mathrm{mole})$. The amounts of radioactivity in the sulphate $(-\mathrm{O}-)$ ) fraction and in the organisms (- were determined. The arrow indicates the completion of thiosulphate utilization.

Oxidation of $\mathrm{S}^{35} \mathrm{SO}_{3}{ }^{2-}$. The radioactivity of the thiosulphate was rapidly transferred to the sulphate fraction, during thiosulphate disappearance; on the completion of thiosulphate utilization, more than $90 \%$ of the ${ }^{35} \mathrm{~S}$ added originally as thiosulphate was in the sulphate fraction (Fig. $3 a$ ). There was negligible accumulation of radioactivity in the organisms.

Oxidation of ${ }^{35} \mathrm{~S}_{-} \mathrm{SO}_{3}{ }^{2-}$. During thiosulphate utilization, the organisms were labelled rapidly; on the completion of thiosulphate disappearance this labelling had reached a peak value equivalent to $80 \%$ of the radioactivity added initially as thiosulphate (Fig. $3 b$ ). As the incubation continued, ${ }^{35} \mathrm{~S}$ accumulated in the sulphate fraction at the expense of the radioactivity within the organisms.

The labelling of the organisms during the oxidation of outer-labelled thiosulphate coincided with the change in turbidity of the suspension. Turbidity changes have been used in this work as a rough measure of intracellular sulphur accumulation during thiosulphate oxidation by suspensions (Fig. 1) in place of the lengthy analytical methods used by other workers (van Niel, 1936; Trüper \& Schlegel, 1964). 


\section{The thiosulphate-cleaving enzyme (rhodanese)}

Crude extracts of the organism catalysed a cyanide-dependent cleavage of thiosulphate to thiocyanate and sulphite, an activity attributed to the enzyme rhodanese. This reaction did not occur with heated extracts.

Rhodanese assay. An assay for the enzyme based on the spontaneous reduction of DCIP by sulphite in the presence of PMS was developed and used to investigate the properties of the enzyme in crude extracts and to follow activity during enzyme fractionation:

$$
\begin{aligned}
& \mathrm{S}_{2} \mathrm{O}_{3}{ }^{2-}+\mathrm{CN}^{-} \rightarrow \mathrm{CNS}^{-}+\mathrm{SO}_{3}{ }^{2-} \\
& \mathrm{SO}_{3}{ }^{2-}+\mathrm{DCIP} \stackrel{\text { PMS }}{\rightarrow} \mathrm{SO}_{4}{ }^{2-}+\text { reduced DCIP. }
\end{aligned}
$$

With partially purified pig kidney rhodanese (Westley \& Green, 1959), this assay method was compared with the standard assay for the mammalian enzyme. The reaction mixture used in the conventional enzyme assay (Sorbo, 1963) was supplemented with DCIP (0.5 $\mu$ mole $/ 3 \mathrm{ml}$.) and PMS (0.25 $\mathrm{mg} . / 3 \mathrm{ml}$.) and dye reduction was followed spectrophotometrically. Enzyme activity using the dye reduction method was $25 \%$ lower than that given by the standard method, but the dye reduction system had the advantage of greater rapidity and sensitivity.

\section{Table 4. Rhodanese activity in extracts of photosynthetic bacteria}

Extracts were prepared from organisms harvested towards the end of growth. The activity of the enzyme in extracts was determined using samples containing $0.25 \mathrm{mg}$. protein $/ \mathrm{ml}$. and the values were corrected for heat-stable activity.

\section{Organism}

Chromatium D

Chromatium D

Chromatium D

Rhodospirillum

rubrum

Rhodopseudomonas

spheroides
Growth substrate

$\mathrm{S}_{2} \mathrm{O}_{3}^{2-}+\mathrm{CO}_{2}$
Pyruvate
Succinate
Malate + glutamate $+0 \cdot 2 \%$
yeast extract

Malate+glutamate
Enzyme activity (units/mg. of protein)

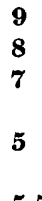

5.5

Properties of the rhodanese activity of crude extracts. The rhodanese activity of crude extracts of the organism was optimal at $\mathrm{pH} 8.7$ and the Michaelis constants of the enzyme for thiosulphate and cyanide were 0.6 and $20 \mathrm{~mm}$ respectively. The enzyme was insensitive to EDTA (10 $\mathrm{mm})$, fluoride $(10 \mathrm{~mm})$, azide (10 mM), thiocyanate (10 mM), cadmium ions (1 mM), arsenite (1 mM) and iodoacetate (1 mM). Tetrathionate (10-40 $\mathrm{mm}$ ) added before or after the initiation of the reaction with cyanide inhibited the enzyme-dependent reduction of DCIP.

The enzyme was found in extracts of Chromatium D grown on succinate and pyruvate and of anaerobically grown Rhodospirillum rubrum and Rhodopseudomonas spheroides. The amounts of enzyme in the extracts of the Athiorhodaceae were approximately half that in the extracts of inorganic grown Chromatium D (Table 4). The activity of the bacterial extracts was less than that in the pig kidney extract; this gave a value of 44 units/mg. protein when assayed in the same way.

Partial purification of the enzyme. The enzyme in crude extracts of inorganic grown Chromatium $D$ was partially purified in a six-stage process (Table 5) 


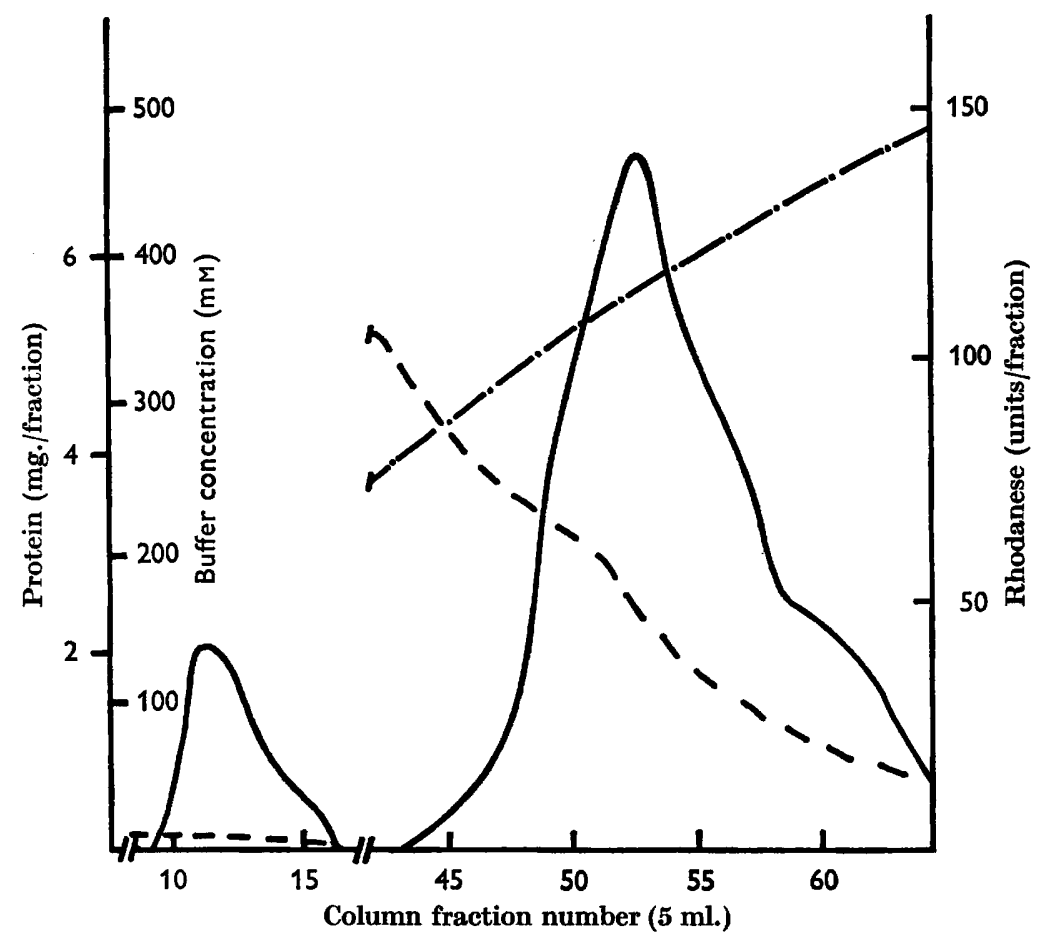

Fig. 4. Chromatography of rhodanese on DEAE cellulose. The protein fraction from stage $V$ was applied to a column of DEAE cellulose. $15 \%$ of the total enzyme recovered passed through the column at low ionic strength (column fractions 10-15 termed fraction A); the remainder of the enzymic activity was eluted from the column with $350-400 \mathrm{~mm}$ buffer (column fractions 49-57 termed fraction B). Protein (-..-), buffer concentration (-...-) and enzyme activity (-) were determined.

Table 5. Partial purification of the rhodanese activity in crude extracts

$$
\text { of Chromatium } D
$$

The details of the individual steps are given in Methods. $5 \mathrm{ml}$. of the concentrated protein fraction from stage IV were applied to the column of Sephadex before chromotagraphy on DEAE cellulose.

\begin{tabular}{|c|c|c|c|c|c|}
\hline Stage & Treatment & $\begin{array}{c}\text { Product } \\
\text { volume } \\
\text { (ml.) }\end{array}$ & $\begin{array}{c}\text { Total } \\
\text { protein } \\
\text { (mg.) }\end{array}$ & $\begin{array}{c}\text { Total } \\
\text { enzyme } \\
\text { (units) }\end{array}$ & $\begin{array}{c}\text { Specific } \\
\text { activity } \\
\text { (units/mg. } \\
\text { protein) }\end{array}$ \\
\hline $\mathbf{I}$ & French press & 30 & 1050 & 12000 & 11 \\
\hline II & High-speed centrifugation & 25 & 450 & 8550 & 19 \\
\hline III & Streptomycin sulphate & 28 & 386 & 7050 & 21 \\
\hline IV & $\begin{array}{l}\text { Ammonium sulphate } \\
0-90 \% \text { saturation }\end{array}$ & 13 & 325 & 6120 & 19 \\
\hline $\begin{array}{l}\text { V } \\
\text { VI }\end{array}$ & $\begin{array}{l}\text { Desalting with Sephadex } \\
\text { Chromatography on DEAE cellulose }\end{array}$ & 12 & 124 & 2107 & 917 \\
\hline & Fraction A nos. (10-15) & 30 & 0.5 & 148 & 296 \\
\hline & Fraction $B$ (nos. 49-57) & 45 & 22 & 887 & 40 \\
\hline
\end{tabular}


involving differential centrifuging, the precipitation of nucleic acid and enzyme with streptomycin sulphate and ammonium sulphate respectively, gel filtration on Sephadex and column chromatography on substituted celluloses. The enzyme was recovered from DEAE cellulose as well as from $\mathrm{CM}$ cellulose in two distinct fractions (Fig. 4). The smaller fraction (A) was unstable during storage and unsuitable for further study; the enzyme in the other fraction (B) was similar in optimum $\mathrm{pH}$, Michaelis constant for thiosulphate and inhibition by tetrathionate to the activity of crude extracts. The enzyme in fraction $B$, after dialysis, was eluted from DEAE cellulose as a single peak of activity.

\section{DISCUSSION}

The growth of Chromatium sp. strain D under autotrophic conditions on sulphide, thiosulphate, exogenous sulphur, and sulphite confirmed the observations of van Niel (1931). The ability to grow on thiosulphate is a feature which Chromatium $D$ has in common with the small Thiorhodaceae (thiopedia and thiocapsa species) and Chlorobium thiosulphatophilum and which distinguishes it from the large purple sulphur bacteria (Chromatium okenii, C. roarmingii, Thiospirillum jenense) and Chlorobium limicola (see Trüper \& Schlegel, 1964). Tetrathionate, a suggested intermediate in the microbial oxidation of thiosulphate, did not support the growth of Chromatium D under autotrophic conditions.

Various workers have reported the intracellular accumulation of sulphur during the growth of Thiorhodaceae on sulphide and thiosulphate (van Niel, 1931, 1936; Eymers \& Wassink, 1937). Sulphur accumulation was a characteristic feature of the growth of Chromatium $D$ on sulphide and thiosulphate and of the oxidation of these sulphur compounds by suspensions of the organism. This sulphur is an endogenous counterpart of the exogenous sulphur compounds required for autotrophic growth as it supported the further growth of the organism in a sulphur-free medium. Endogenous sulphur accounted for up to $27 \%$ of the dry weight of the organism; similar amounts of sulphur accumulate in other Thiorhodaceae during growth on sulphide (van Niel, 1936; Trüper \& Schlegel, 1964). The chemical nature of this endogenous sulphur is not known. Intracellular sulphur bears some analogy to poly- $\beta$-hydroxybutyrate, which accumulates in photosynthetic bacteria during growth under certain conditions on organic media (Stanier, Doudoroff, Kunisawa \& Contopoulou, 1959; Doudoroff \& Stanier, 1959). Endogenous sulphur resembles the polymer in the magnitude of accumulation, in its requirements for utilization and in its ability to support further growth. Both accumulants are a potential source of reducing power within the organism although poly- $\beta$-hydroxybutyrate is also a source of fixed carbon.

During thiosulphate utilization by suspensions of Chromatium $\mathbf{D}$, the inner $\left(\mathrm{SO}_{3^{-}}\right)$atom was rapidly oxidized to sulphate whilst the outer (S-) atom largely accumulated as endogenous sulphur. On the completion of thiosulphate disappearance, more than $90 \%$ of the inner atom and $15 \%$ of the outer atom of thiosulphate were in the sulphate fraction; the remainder of the outer atom was within the organisms and was oxidized to sulphate at a relatively slow rate compared with the inner atom. At least $80 \%$ of the outer atom of thiosulphate passed through the stage of endogenous sulphur, implying that it was an intermediate in the oxidation 
of thiosulphate to sulphate by Chromatium D. Endogenous sulphur has a similar intermediate role in the oxidation of sulphide by Chromatium okenii (Trüper, 1964). In the present work the results indicated that the inner and outer sulphur atoms of thiosulphate were oxidized at different rates and therefore independently to sulphate. This requires the separation of the two sulphur atoms of thiosulphate at an early stage in the oxidation process. The fact that Chromatium $D$ grew on, and oxidized, sulphide, sulphur and sulphite but not tetrathionate was consistent with the key role envisaged for thiosulphate cleavage in the oxidation process (Fig. 5). The role of rhodanese in the oxidation of thiosulphate by Chromatium $\mathbf{D}$ remains to be proved, especially since the enzyme was also found in Athiorhodaceae. It could, however, be concerned in the initial cleavage reaction. A double displacement mechanism has recently been proposed for the reaction catalysed by the mammalian enzyme (Green \& Westley, 1961; Westley \& Nakamoto, 1962; Villarejo $\&$ Westley, $1963 a, b)$ involving the formation of an enzyme-sulphur intermediate.

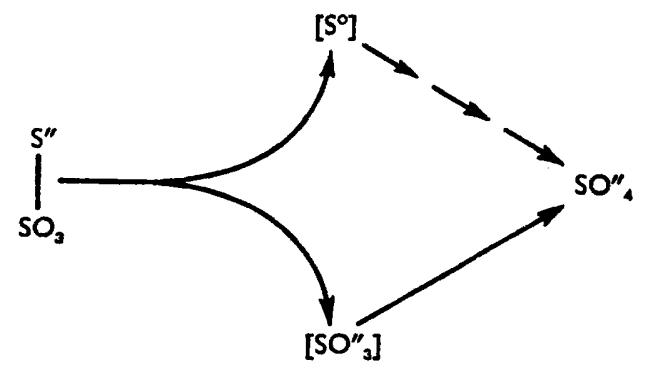

Fig. 5. The complete oxidation of thiosulphate.

The enzyme is regenerated in a reaction with an acceptor molecule such as cyanide or reduced lipoic acid. In the case of the oxidation of thiosulphate by Chromatium $D$, a reaction mechanism is envisaged in which a physiological acceptor reacts with an enzyme-sulphur intermediate to give sulphur or a closely related compound. Reactions other than the cyanide-dependent cleavage of thiosulphate catalysed by Chromatium rhodanese have yet to be demonstrated.

Although the mechanism of the oxidation of inorganic sulphur compounds by coloured and colourless sulphur bacteria are apparently different in detail, the oxidation process in both groups of organisms is closely associated with the production of reducing power for the fixation of carbon dioxide and subsequent biosynthetic reactions. The growth yields of Chromatium $\mathrm{D}$ in media containing a variety of reduced inorganic sulphur compounds were consistent with the electron donor role of the sulphur compound in bacterial photosynthesis (van Niel, 1931). The nature of the electron acceptors directly involved in the oxidation of sulphur compounds by Chromatium $\mathbf{D}$ is, however, unknown.

This research was aided by a grant from the Department of Scientific and Industrial Research and from the Rockefeller Foundation. A.J.S. wishes to thank the Agricultural Research Council for a Research Studentship. 


\section{REFERENCES}

Basford, R. E. \& Huennekens, F. M. (1955). Studies on thiols. I. Oxidation of thiol groups by 2,6-dichlorophenol-indophenol. J. Am. chem. Soc. 77, 3873.

DounonofF, M. \& Stanier, R. Y. (1959). Role of poly- $\beta$-hydroxybutyric acid in the assimilation of organic carbon by bacteria. Nature, Lond. 183, 1440.

Eymers, J. G. \& WASsink, E. C. (1937). On the photochemical carbon dioxide assimilation in purple sulphur bacteria. Enzymologia, 2, 258.

Grlman, A. (1946). The nephrotoxic action of tetrathionate. Am. J. Physiol. 147, 115.

Gleen, H. \& Quastel, J. H. (1953). Sulphur metabolism in soil. Appl. Microbiol. 1, 70.

Green, J. R. \& Westley, J. (1961). Mechanism of rhodanese action: polarographic studies. J. biol. Chem. 236, 3047.

Hurlbert, R. E. \& Lascellees, J. (1963). Ribulose diphosphate carboxylase in Thiorhodaceae. J. gen. Microbiol. 33, 445.

LARSEN, H. (1952). On the culture and general physiology of the green sulphur bacteria. J. Bact. 64, 187.

LARSEN, H. (1953). On the microbiology and biochemistry of the photosynthetic green sulphur bacteria. $K$. norske Vidensk. Selsk. Skr. NR 1.

LASCElles, J. (1959). Adaptation to form bacteriochlorophyll in Rhodopseudomonas spheroides: changes in activity of enzymes concerned in pyrrole synthesis. Biochem. J. 72, 508.

LAYNE, E. (1957). Spectrophotometric and turbidimetric methods for measuring proteins. Advanc. Enzymol. 3, 447.

VAN NIEL, C. B. (1931). On the morphology and physiology of the purple and green sulphur bacteria. Arch. Mikrobiol. 3, 1 .

van Niel, C. B. (1936). On the metabolism of the Thiorhodaceae. Arch. Mikrobiol. 7, 323.

PeCK, H. D. (1960). Adenosine 5' ${ }^{\prime}$-phosphosulphate as an intermediate in the oxidation of thiosulphate by Thiobacillus thioparus. Proc. natn. Acad. Sci. U.S.A. 46, 1053.

Peck, H. D. \& Fisher, E. (1962). The oxidation of thiosulphate and phosphorylation in extracts of Thiobacillus thioparus. J. biol. Chem. 237, 190.

Ritrenberg, S. C. \& London, J. (1964). Path of sulphur in sulphide and thiosulphate oxidation by thiobacilli. Proc. natn. Acad. Sci. U.S.A. 52, 1183.

Schöön, N. H. (1959). Colorimetric determination of thiosulphate in the presence of polythionates and hydrogen sulphide. Acta chem. scand. 13, 525.

Smith, A. J. (1964). Sulphur metabolism of Chromatium strain D and rhodanese activity in extracts. J. gen. Microbiol. 34, ix.

Smith, A. J. (1965). The discriminative oxidation of the sulphur atoms of thiosulphate by a photosynthetic sulphur bacterium-Chromatium strain D. Biochem. J. 94, 27 P.

Sorbo, B. (1957). A colorimetric method for the determination of thiosulphate. Biochim. biophys. Acta, 23, 412 .

Sorbo, B. (1963). On the reaction between $p$-chloromercuribenzoate and rhodanese. Acta chem. scand. 17 suppl., 1, 107.

Stanier, R. Y., Doudoroff, M., Kunisawa, R. \& Contopoulou, R. (1959). The role of organic substrates in bacterial photosynthesis. Proc. natn. Acad. Sci. U.S.A. 45, 1246.

Starkey, R. L. (1935). Products of the oxidation of thiosulphate by bacteria in mineral media. J. gen. Physiol. 18, 325.

TAmya, H., HAGA, K. \& Huzisige, H. (1941). On the physiology of the chemoautotrophic sulphur bacteria. Acta phytochim., Tokyo, 12, 173.

TAUSSKY, H. H. \& SchorR, E. (1953). A microcolorimetric method for the determination of inorganic phosphorus. J. biol. Chem. 202, 675.

Trudinger, P. A. (1958). Cytochromes and thiosulphate oxidation in an aerobic thiobacillus. Biochim. biophys. Acta, 30, 211.

Trudinger, P. A. (1959.) The initial products of thiosulphate oxidation by Thiobacillus X. Biochim biophys. Acta. 31, 270. 
TrüPER, H. G. (1964). Sulphur metabolism in Thiorhodaceae. II. Stoicheiometric relationship of carbon dioxide fixation to oxidation of hydrogen sulphide and intracellular sulphur in Chromatium okenii. Antonie van Leeurwenhoek, 30, 385.

TrüPer, H. G. \& Schleger, H. G. (1964). Sulphur metabolism in Thiorhodaceae. I. Quantitative measurements on growing cells of Chromatium okenii. Antonie van Leeurvenhoek, 30, 225.

Villakejo, M. \& Westley, J. (1963a). Rhodanese-catalysed reduction of thiosulphate by reduced lipoic acid. J. biol. Chem. 238, PC1185.

ViLLAREJo, M. \& WeStley, J. (1963b). Mechanism of rhodanese catalysis of thiosulphatelipoate oxidation-reduction. J. biol. Chem. 238, 4016.

Visiniac, W. (1952). The metabolism of Thiobacillus thioparus. I. The oxidation of thiosulphate. J. Bact. 64, 363.

Vishntac, W. \& Santer, M. (1957). The thiobacilli. Bact. Rev. 21, 195.

Westuey, J. \& Green, J. R. (1959). Crystalline beef kidney rhodanese. J. biol. Chem. 234, 2325.

Westley, J. \& Nakamoto, T. (1962). Mechanism of rhodanese action: isotopic tracer studies. J. biol. Chem. 237, 547. 